\title{
Export stoichiometry and contribution of copepod faecal pellets to vertical flux of particulate organic carbon, nitrogen and phosphorus
}

\author{
Tobias Tamelander*, Anaïs B. Aubert, Christian Wexels Riser \\ Department of Arctic and Marine Biology, University of Tromsø, 9037 Tromsø, Norway
}

\begin{abstract}
Sinking of particles is a key mechanism in the transport of organic matter from the ocean's productive surface layer to the deep sea and sediments, but also constitutes a loss of carbon and growth-limiting nutrients to the pelagic food web. Knowledge on export of particulate phosphorus is limited, particularly in high-latitude regions, in spite of its role as a co-limiting factor in many marine systems. We therefore investigated suspended concentrations and vertical export (by means of sediment traps) of particulate organic carbon (POC), nitrogen (PON) and total particulate phosphorus (TPP) at 3 contrasting sites in the Fram Strait and Barents Sea opening and quantified the contribution of zooplankton faecal pellets to POC, PON and TPP export. The TPP fluxes are the first to be reported from this region and probably the first from the entire Arctic Ocean. The suspended and exported C:N ratios were close to the Redfield ratio and did not differ significantly from each other (mean atomic ratios of 6.1 and 6.3, respectively). The mean C:P of suspended particles (91) was below Redfield, whereas the exported mean (117) exceeded Redfield, indicating more efficient retention of phosphorus than of nitrogen in the water column. Copepod faecal pellets had low C:P ratios and contributed a higher proportion to phosphorus export (mean of $17 \%$ ) than to carbon and nitrogen export $(10 \%)$. Faecal pellets may therefore be an important loss factor for phosphorus from the water column compared to slower-sinking material, which is retained more efficiently.
\end{abstract}

KEY WORDS: Vertical flux - Carbon · Nitrogen - Phosphorus - Stoichiometry - Faecal pellets · Calanus spp. A Arctic

Resale or republication not permitted without written consent of the publisher

\section{INTRODUCTION}

Vertical export of particulate organic matter constitutes an important part of the biological carbon pump and is the primary food input to organisms inhabiting depths below the ocean's productive surface layer. In oceanic systems, the magnitude and composition of vertical flux is controlled by autochthonous production of organic matter and by consumption and degradation of organic matter in the pelagic food web. Vertical export reduces the availability of carbon and growth-limiting nutrients (nitrogen and phosphorus) in the surface layer, and export of nitrogen and phosphorus may therefore contribute to enhancing nutri- ent limitation. Knowledge of export stoichiometry and a comprehension of the regulating mechanisms are therefore crucial to understanding carbon and nutrient cycling and export potential in the ocean.

Several studies have documented persistent deviations from the Redfield C:N ratio of 6.6 by atoms (Redfield 1934, Redfield et al. 1963) both for nutrient uptake (Mei et al. 2005), suspended particulate biomass (Sterner et al. 2008) and export production (Körtzinger et al. 2001). C:N ratios of particulate organic matter above Redfield seem to be a common feature in high-latitude systems (Daly et al. 1999, Loh \& Bauer 2000, Olli et al. 2002) and have been accounted for in production estimates (Smith et al. 
1997, Tremblay et al. 2002) and ecosystem models developed for these regions (Tian et al. 2003, Wassmann et al. 2006). However, more knowledge is needed on the variability and regulation of export stoichiometry in order to correctly construct carbon budgets and models and, hence, improve the understanding of biological productivity and export in marine systems (Boyd \& Trull 2007). In particular, the role of the pelagic food web in mediating fluxes of carbon and limiting nutrients needs to be further elucidated. Microbial degradation typically leads to faster dissolution of nitrogen and phosphorus than of carbon, and these elements are therefore retained more efficiently in the water column (reviewed by Boyd \& Trull 2007). The role of zooplankton grazing for shaping the export stoichiometry is less well known. Copepods assimilate nitrogen more efficiently than carbon, reflected in carbon enrichment in faecal pellets relative to the diet (Checkley \& Entzeroth 1985, Daly et al. 1999). Faecal pellets may temporarily be important for carbon export (Turner 2002, Wexels Riser et al. 2008), but their potential role as a loss factor for nitrogen and phosphorus has not been thoroughly investigated in various marine systems. Excretion by zooplankton at depth during their vertical migration is an important loss factor for phosphorus in tropical regions where passive sinking is relatively small (Hannides et al. 2009). The lack of synchronised diel vertical migration in Arctic zooplankton during the midnight sun period suggests that this pathway is negligible in the Arctic (Blachowiak-Samolyk et al. 2006, Cottier et al. 2006, Wexels Riser et al. 2007). The seasonal descent of ontogenetically migrating copepods to overwintering depths contributes significantly to the biological carbon pump in addition to the passive sinking flux of faecal pellets and carcasses (Steinberg et al. 2008, Sampei et al. 2012).

While most investigations in nitrogen-limited environments have focused on carbon and nitrogen fluxes, phosphorus has the potential to act as a colimiting nutrient and, hence, contribute to regulating carbon export (Thingstad \& Rassoulzadegan 1995). Phosphorus is becoming increasingly recognised as the limiting nutrient in some parts of the ocean (Karl et al. 2001, Vidal et al. 2003, Hannides et al. 2009). Phosphorus limitation may also occur seasonally in primarily nitrogen-limited systems (Tamminen \& Seppälä 1999). It is well known that Pacific and Atlantic waters present in the Arctic differ in their inorganic N:P ratio, with Pacific water exhibiting a surplus of phosphorus. Damm et al. (2010) recently showed that the excess phosphorus in the Pacific water supports methane production by bacteria, which does not take place in the phosphorus-poor Atlantic water. Particle export leads to reduced availability of nutrients in the water column and may, hence, provide a feedback mechanism to methane, which is a strong greenhouse gas. However, export of particulate phosphorus from the water column has not been investigated in these regions.

Earlier vertical flux studies in the Arctic have focused on carbon and nitrogen, and export regulation by the pelagic food web (reviewed by Wassmann et al. 2004, see also Reigstad et al. 2008, Lalande et al. 2009, Forest et al. 2010, Sallon et al. 2011). We investigated the C:N:P stoichiometry of suspended and exported particulate organic matter at 3 hydrographically distinct locations in the European Arctic. Retention efficiencies were determined based on snapshot views of the elemental ratios of contemporaneously sampled suspended and exported biomass, and we hypothesised that the retention of nitrogen and phosphorus in the water column would be equally efficient. We further quantified the contribution of zooplankton faecal pellets to vertical flux of carbon, nitrogen and phosphorus. Large faecal pellets are an important vehicle for organic matter export from the upper water layers due to their fast sinking speed. They are interesting from a stoichiometric standpoint because they derive from consumers whose requirements for elements differ from those of primary producers. This export pathway has previously not been investigated in the Arctic Ocean.

\section{MATERIALS AND METHODS}

\section{Sampling}

Sampling took place in June 2009 during a cruise with the RV 'GO Sars' to the Greenland Sea, Fram Strait and Barents Sea. Three main stations with sediment trap deployments were located in the Eastern Fram Strait at depths of $1200 \mathrm{~m}$ (Stn 65) and $3000 \mathrm{~m}$ (Stn 74) and in the Barents Sea opening over the continental shelf at a depth of $470 \mathrm{~m}$ (Stn 100, Fig. 1). Stns 65 and 74 were located in open water but were influenced by drift ice, which was still present at Stn 65. Stn 100 was outside the reach of the seasonal ice-cover in the Barents Sea. Zooplankton and suspended organic matter were also sampled at 1 station in the Greenland Sea (Stn B).

CTD profiles and samples for suspended particles were collected with a Seabird CTD and Niskin bot- 


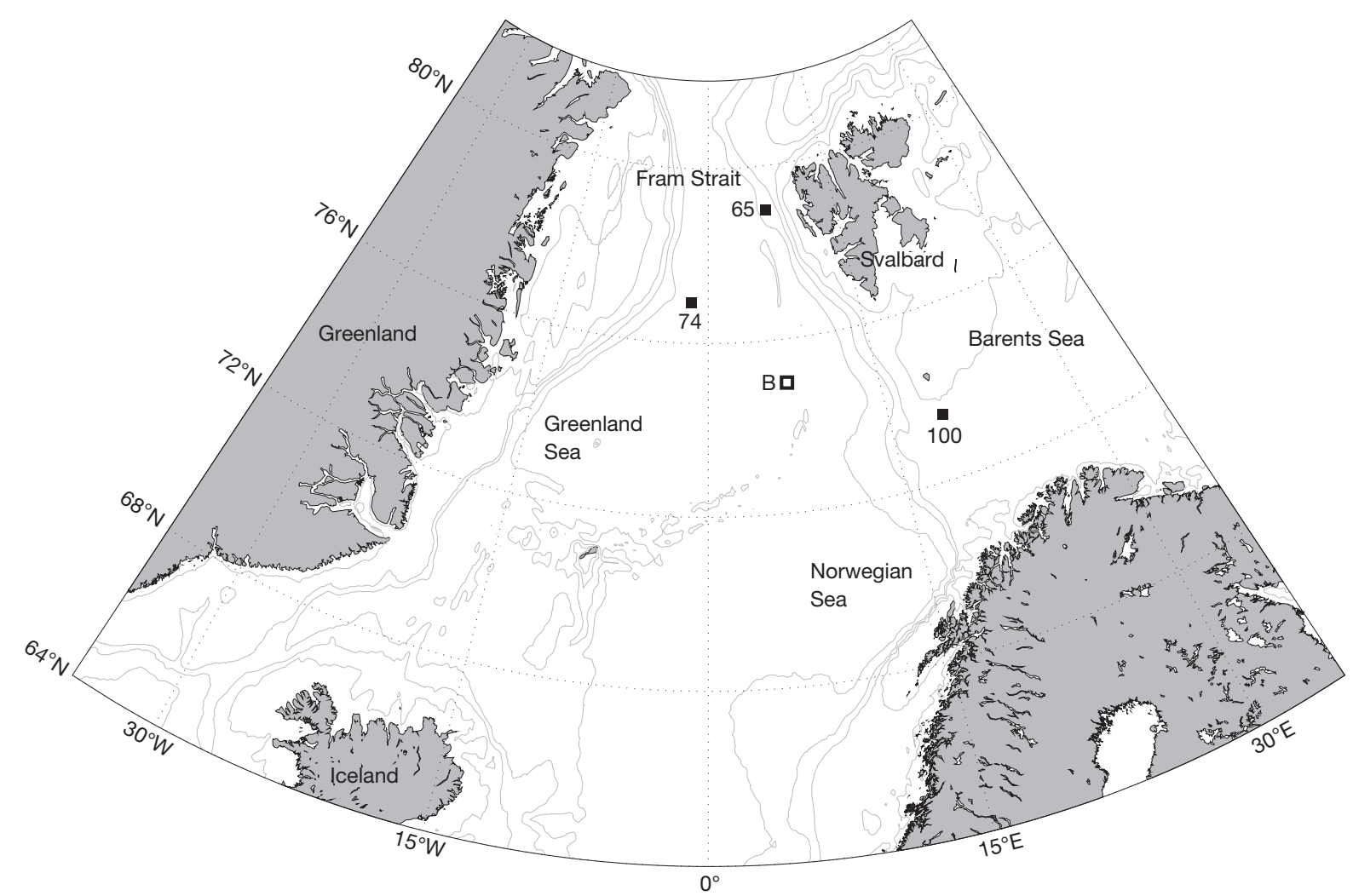

Fig. 1. Study region, with bathymetry (200, 500, 1000 and $2000 \mathrm{~m}$ isobaths) and sampling locations indicated. Black squares indicate the main stations (Stns 65, 74 and 100) with sediment trap deployments. Zooplankton and suspended organic matter were also sampled at Stn B

tles mounted on the Rosette from 10 fixed depths $(5,10,20,30,40,50,60,90,120$ and $200 \mathrm{~m})$. Vertically exported particles were collected by means of surface-tethered sediment traps attached to a drifter at $20,30,40,50,60,90,120,150$ and $200 \mathrm{~m}$ depth. No fixatives were used in the traps. The samples from 40 and $150 \mathrm{~m}$ were used for analyses not covered in this study. The collection time varied between 15 and $24 \mathrm{~h}$. The sediment traps (KC Maskiner og laboratorieudustyr) consisted of parallel cylinders with an inner diameter of $7.2 \mathrm{~cm}$ (height:diameter ratio of 6.25) mounted in a gimballed frame equipped with a vane. At moderate current velocities, the cylinders stay vertical and perpendicular to the current direction (Coppola et al. 2002). The trapping efficiency for particulate organic carbon (POC) is 90 to $110 \%$, determined by comparison with the ${ }^{234}$ Thorium method (Coppola et al. 2002). The larger discrepancy between fluxes measured by sediment traps and thorium, respectively, observed by Lalande et al. (2008) was due to variations in the ${ }^{234} \mathrm{Th}$ POC ratio during blooms dominated by Phaeocystis. These sediment traps are considered to provide representative estimates of the actual vertical particle flux.
Upon retrieval, the contents of the 2 parallel cylinders were pooled into 1 sample from each depth. Aliquots were filtered in triplicate on GF/F filters for determination of chlorophyll a ( $\mathrm{chl}$ a) and on precombusted $\left(450^{\circ} \mathrm{C}, 4 \mathrm{~h}\right) \mathrm{GF} / \mathrm{F}$ filters for POC and particulate organic nitrogen (PON) and total particulate phosphorus (TPP) from both water bottle and sediment trap samples. Chl a was determined on board, whereas the samples for elemental analyses were stored frozen at $-20^{\circ} \mathrm{C}$ until analysed. Samples for enumeration and size measurements of faecal pellets were fixed with buffered formalin to a final concentration of $2 \%$. Faecal pellets were enumerated in sample aliquots at $100 \times$ magnification using an inverted microscope. The lengths and widths of all pellets (43 to 177 per sample) were measured, and the volumes of pellets were calculated assuming a cylindrical shape. Faecal pellet volumes were converted to carbon, nitrogen, and phosphorus based on experimentally determined volumetric conversion factors (see 'Volumetric conversion factors and faecal pellet export' below).

Zooplankton was sampled with a WP-2 plankton net with $180 \mu \mathrm{m}$ mesh size from $100 \mathrm{~m}$ depth to sur- 
face. One haul was fixed with buffered formalin to a final concentration of $4 \%$ for determination of composition and abundance of zooplankton taxa. The sampling volume was estimated by sampling depth $(100 \mathrm{~m})$ times the area of the net opening $\left(0.255 \mathrm{~m}^{2}\right)$. A second haul was taken with a non-filtering codend to collect animals to determine the elemental content of faecal pellets. This sample was gently diluted in 201 of seawater collected from the ship's water intake at $5 \mathrm{~m}$ depth and kept at close to in situ temperature.

\section{Analyses}

Samples for chl a were extracted in methanol overnight in darkness and at room temperature (HolmHansen \& Riemann 1978). After homogenisation, fluorescence was measured on a Turner AU-10 fluorometer calibrated with pure chl a (Sigma S6144) before and after adding 2 drops of $5 \% \mathrm{HCl}$.

POC and PON samples were dried at $60^{\circ} \mathrm{C}$ and exposed to $\mathrm{HCl}$ fumes for $24 \mathrm{~h}$ in order to remove carbonates. The $\mathrm{C}$ and $\mathrm{N}$ content was determined on a Leeman Lab CEC 440 CHN analyser and corrected for background contamination determined in blank filters.

TPP analyses followed a slightly modified version of Strickland \& Parsons (1965). The dried filters $\left(60^{\circ} \mathrm{C}\right.$ overnight) were 'dry digested' by burning at $450^{\circ} \mathrm{C}$ for $4 \mathrm{~h}$ prior to digestion in a $\mathrm{K}_{2} \mathrm{~S}_{2} \mathrm{O}_{8}$ solution at $125^{\circ} \mathrm{C}$ for $30 \mathrm{~min}$. Dry digestion has been shown to make particulate phosphorus more soluble and to reduce variability among replicates (Walve \& Larsson 1999). The digested material was put in reaction with ascorbic acid and a molybdate solution, after which the absorbance was determined at $880 \mathrm{~nm}$ with a Hitachi U-2900 spectrophotometer. Blank filters were carried through the same procedure. Standard curves were prepared for each batch of samples based on a stock phosphate solution of known concentration.

The zooplankton community samples were analysed for the abundance of copepods. Stages were identified in the 3 Calanus species and in Metridia longa but not in the smaller species which were not sampled quantitatively by the $180 \mu \mathrm{m}$ mesh WP2 net (Svensen et al. 2011). A minimum of 400 individuals were counted per sample, and successive aliquots were included until at least 150 specimens of the most abundant calanoid species were encountered. Abundance was converted to biomass using published stage-specific individual dry weights (Conover \& Huntley 1991, Sabatini \& Kiørboe 1994, Karnovsky et al. 2003, Blachowiak-Samolyk et al. 2008).

\section{Volumetric conversion factors and faecal pellet export}

Volumetric conversion factors for faecal pellets were determined at Stns B, 65 and 74 to estimate vertical flux of faecal pellet carbon (FPC), nitrogen (FPN) and phosphorus (FPP). Animals in the live zooplankton sample were sorted under magnification (dissecting stereoscope) and transferred to seawater dishes kept on ice using a wide-tip pipette. Batches of 15 to 20 healthy Calanus finmarchicus CV individuals (Stns 65 and 74) and C. hyperboreus CV (Stn B) were then gently emptied into each of 3 glass beakers (1.8 l) containing water from the depth of maximum fluorescence. After incubation for 17 to $26 \mathrm{~h}$ in darkness in a temperature-controlled room at close to in situ temperature $\left(2^{\circ} \mathrm{C}\right.$ at $\mathrm{Stn} 74$ and $5^{\circ} \mathrm{C}$ elsewhere), the contents of the incubation chambers were gently filtered through a $10 \mu \mathrm{m}$ mesh. The faecal pellets retained on the mesh were transferred through 3 baths of GF/F-filtered seawater by micropipette to remove algal cells and detritus. A known number of intact Calanus pellets were then collected on pre-combusted glass fibre filters for determination of C, N (100-260 pellets per filter, 1-4 filters per station), and $\mathrm{P}$ (40-150 pellets per filter, 2-4 filters per station) contents. The volume of pellets was estimated in the sediment trap samples, assuming that cylindrical pellets with a diameter of 50 to $90 \mu \mathrm{m}$ derived from Calanus spp. CVs or adults (Reigstad et al. 2005, Wexels Riser et al. 2008). The volumetric conversion factors (mean $\pm \mathrm{SD}$ ) thus obtained were $63.0 \pm 23.7 \mu \mathrm{g} \mathrm{C} \mathrm{mm}{ }^{-3}, 11.7 \pm 2.7 \mu \mathrm{g} \mathrm{N} \mathrm{mm}{ }^{-3}$ and 2.4 $\pm 0.3 \mu \mathrm{g} \mathrm{P} \mathrm{mm}^{-3}$. Since cylindrical pellets from large copepods by far dominated the number of faecal pellets in the sediment traps, we did not attempt to quantify the input from sources other than cylindrical pellets.

\section{RESULTS}

\section{Physical environment and chl a}

The main stations with sediment trap deployments were located in Atlantic water with the core of the upper $200 \mathrm{~m}$ exhibiting $>0{ }^{\circ} \mathrm{C}$ temperature and salinity close to 35 (Fig. 2). Stn 74 was cooler, however, with temperatures between -0.3 and $2.7^{\circ} \mathrm{C}$. The influence of ice melt was reflected in a cold and relatively fresh surface layer, resulting in stronger and shallower stratification compared to the other stations (Table 1). The homogenous depth distribution 

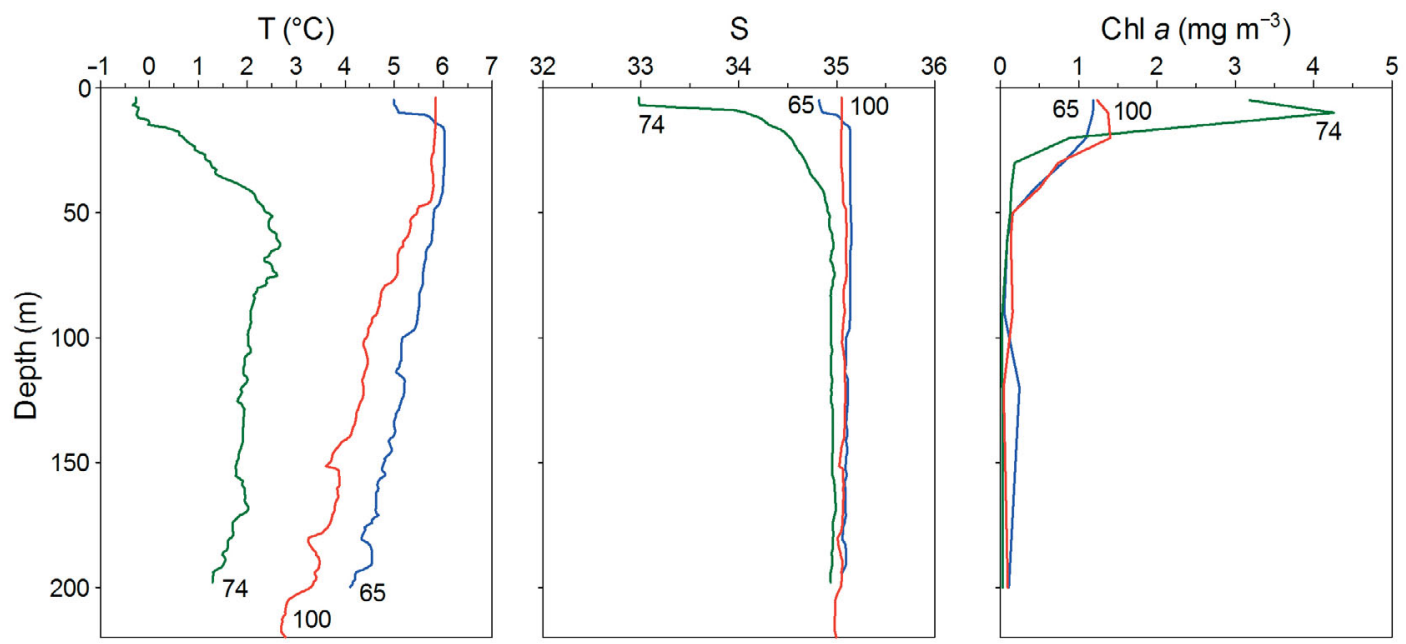

Fig. 2. Vertical distribution of temperature (T), salinity (S) and chlorophyll a (chl a) in the upper $200 \mathrm{~m}$ of the water column at Stns 65 (blue), 74 (green) and 100 (red)

Table 1. Main characteristics of the sediment trap stations. Mixed layer depth (MLD), chlorophyll a (chl a) biomass, abundance and biomass (dry weight [DW]) of Calanus spp. copepods, particulate organic carbon (POC) export and contribution of copepod faecal pellets to POC export (\% faecal pellet carbon, FPC)

\begin{tabular}{|c|c|c|c|c|c|c|}
\hline Station & $\begin{array}{l}\text { MLD } \\
(\mathrm{m})\end{array}$ & $\begin{array}{c}\mathrm{Chl} a^{\mathrm{a}} \\
\left(\mathrm{mg} \mathrm{m}^{-2}\right)\end{array}$ & $\begin{array}{l}\text { Calanus } \\
\text { abundance } \\
\text { (ind. } \mathrm{m}^{-2} \text { ) }\end{array}$ & $\begin{array}{l}\text { Calanus } \\
\mathrm{DW}^{\mathrm{b}} \\
\left(\mathrm{mg} \mathrm{m}^{-2}\right)\end{array}$ & $\begin{array}{c}\text { POC } \\
\operatorname{export}^{\mathrm{C}} \\
\left(\mathrm{mg} \mathrm{m}^{-2} \mathrm{~d}^{-1}\right)\end{array}$ & $\begin{array}{c}\% \mathrm{FPC}^{\mathrm{c}} \\
(\%)\end{array}$ \\
\hline 65 & 10 & 64 & 8458 & 442 & 157 & 8 \\
\hline 74 & 8 & 77 & 10375 & 5269 & 342 & 15 \\
\hline 100 & 45 & 62 & 9233 & 179 & 147 & 7 \\
\hline \multicolumn{7}{|c|}{$\begin{array}{l}\text { aDepth-integrated concentration for the } 0-200 \text { m layer } \\
\text { bDepth-integrated abundance for the } 0-100 \mathrm{~m} \text { layer } \\
{ }^{\mathrm{c}} \text { Mean of all measurements in the } 20-200 \mathrm{~m} \text { layer }\end{array}$} \\
\hline
\end{tabular}

of $4 \mathrm{mg} \mathrm{m}^{-3}$, while it was close to $1 \mathrm{mg}$ $\mathrm{m}^{-3}$ at the other stations (Fig. 2). The depth-integrated chl a biomass was highest at Stn 74 (Table 1)

\section{Copepod biomass and composition}

Total copepod biomass varied by an order of magnitude among stations and was highest at Stn 74 (Fig. 3). Calanus spp. dominated the zooplankton biomass at all stations. Among Calanus spp., C. finmarchicus was the most abundant, but at Stn 74, C. hyperboreus dominated in terms of of temperature and salinity at Stn 100 likely resulted from a storm event during the days preceding sampling at this location, causing deep mixing of the water column.

All stations revealed an accumulation of chl $a$ in the upper $50 \mathrm{~m}$, with maximum concentration between 0 and $20 \mathrm{~m}$. Stn 74 had a maximum chl a concentration biomass. At this location, Calanus spp. accounted for $95 \%$ of total zooplankton biomass, whereas this pro(71-82\%; Fig. 3). The stage composition of Calanus copepodites differed among stations (not shown). CV dominated the biomass at Stn 65 and CIII at Stn 100. Stn 74 had a higher relative abundance of CVs and portion was slightly smaller at the other stations
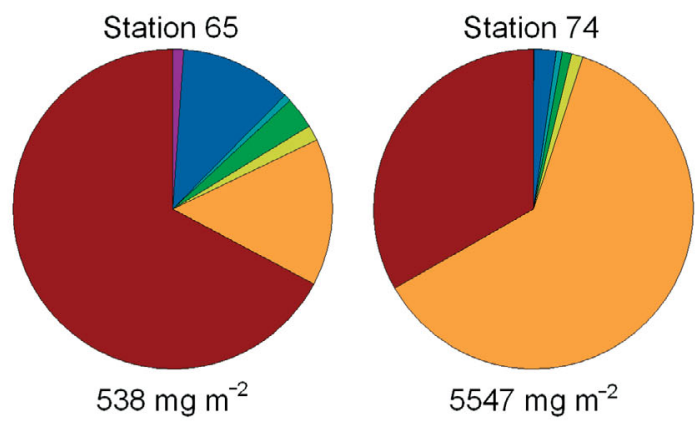

$5547 \mathrm{mg} \mathrm{m}^{-2}$
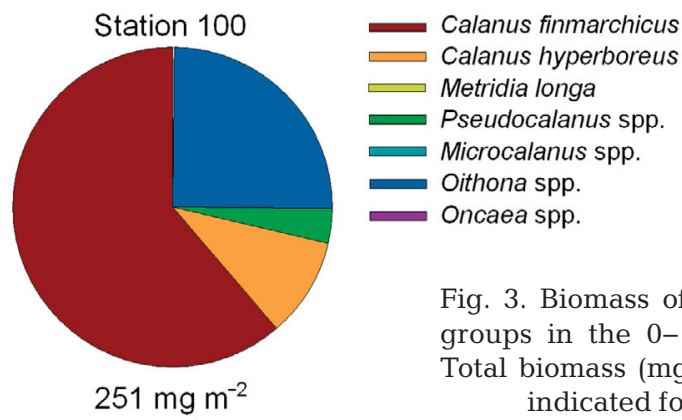

Fig. 3. Biomass of the main copepod groups in the $0-100 \mathrm{~m}$ depth layer. Total biomass (mg dry weight $\mathrm{m}^{-2}$ ) is indicated for each station 
adult females of both C. finmarchicus and C. hyperboreus which contributed to higher zooplankton biomass at this station. The biomass of Metridia longa, Pseudocalanus spp. and smaller copepods such as Oithona spp., Microcalanus spp. and Oncaea spp. differed among stations, but the proportion of these species together never exceeded $30 \%$ of the total biomass. However, the abundance and biomass of these taxa were probably underestimated since zooplankton was sampled with a $180 \mu \mathrm{m}$ mesh.

\section{Vertical flux of POC, PON, TPP and faecal pellets}

Vertical flux was highest at Stn 74, with 265 to $430 \mathrm{mg}$ POC m${ }^{-2} \mathrm{~d}^{-1}, 48$ to $83 \mathrm{mg} P O N \mathrm{~m}^{-2} \mathrm{~d}^{-1}$ and 5 to $10 \mathrm{mg}$ TPP $\mathrm{m}^{-2} \mathrm{~d}^{-1}$. The fluxes were slightly higher at Stn 65 than at Stn 100, but clearly lower than at Stn 74 (Fig. 4). At Stns 65 and 74, the vertical flux of all constituents declined with depth, being lowest at $200 \mathrm{~m}$. At Stn 65, the POC flux decreased most sharply below $120 \mathrm{~m}$ depth, whereas a decrease
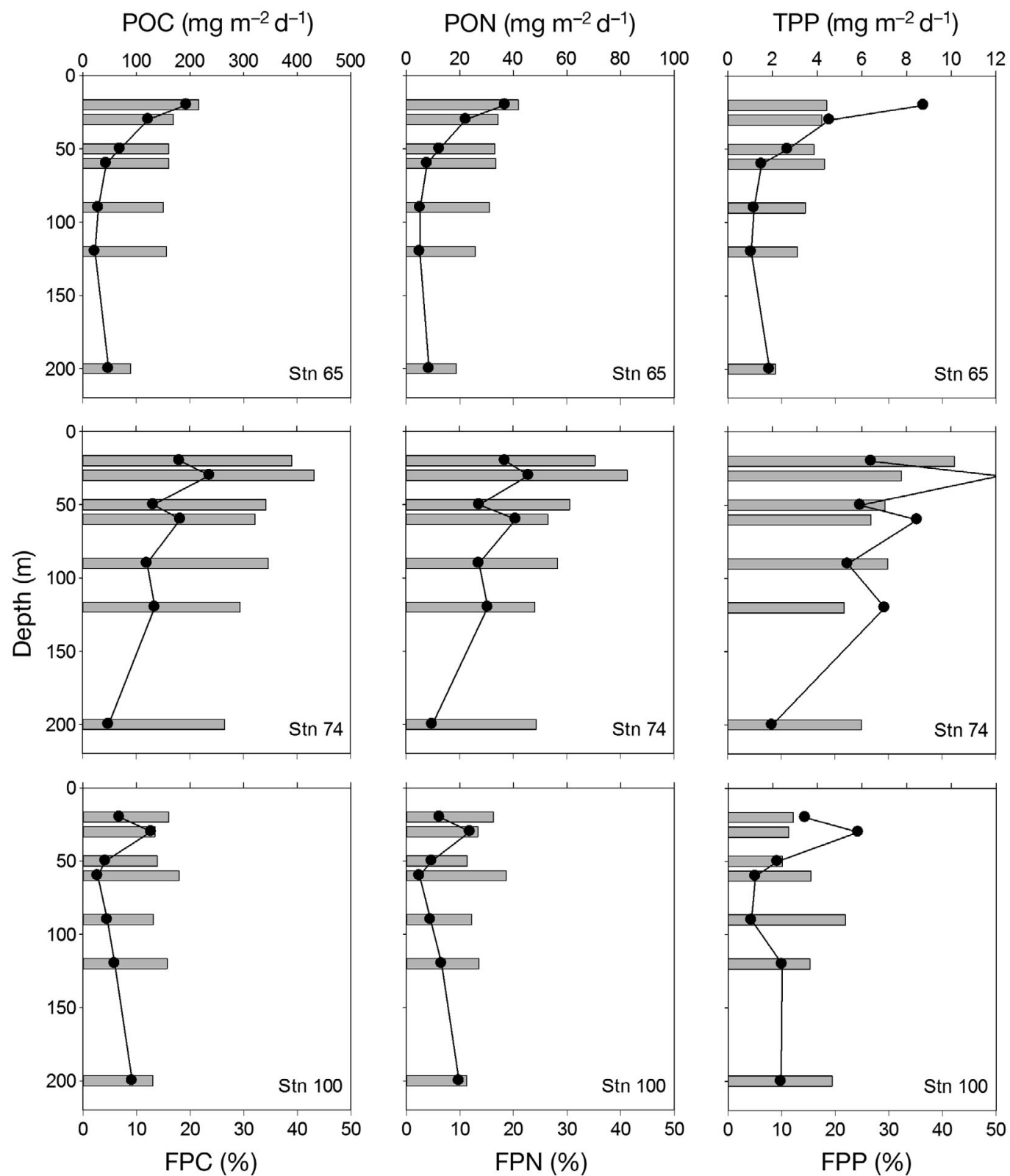

Fig. 4. Vertical flux (bars, upper $x$-axes) of particulate organic carbon, nitrogen, and total particulate phosphorus (POC, PON and TPP, respectively) at Stns 65, 74 and 100. Percentages of copepod faecal pellet C, N and P (FPC, FPN, FPP, respectively) of the total POC, PON and TPP fluxes are indicated by points and lines (lower $x$-axes) 


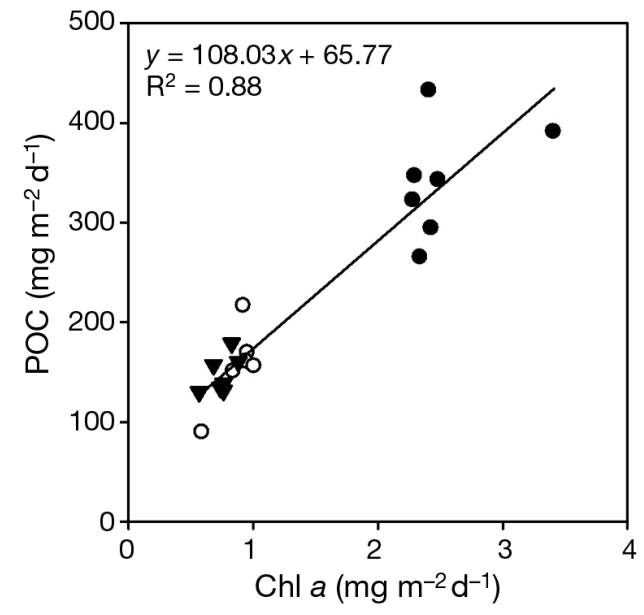

Fig. 5. Relationship between vertical flux of particulate organic carbon (POC) and chlorophyll a (chl a) across all observations (Stn 65: O, Stn 74:, Stn 100: $\boldsymbol{\nabla})$

in PON and TPP was already evident below $60 \mathrm{~m}$. At Stn 74, the fluxes did not decrease monotonously, but there appeared to be a decline in all constituents between 30 and $60 \mathrm{~m}$. At Stn 100, fluxes hardly decreased even below $120 \mathrm{~m}$ depth. The PON fluxes generally revealed the same depth variation as the POC fluxes. TPP fluxes increased between 120 and $200 \mathrm{~m}$ at 2 stations, but otherwise revealed the same trends as the POC and PON fluxes (Fig. 4). A linear regression of the vertical flux of POC on chl a across all stations and depths revealed a strong positive relationship, with a mean POC:chl a ratio of 108 for the exported organic matter $\left(\mathrm{R}^{2}=0.88, \mathrm{p}<0.0001\right.$, df = 20, Fig. 5).

Cylindrical copepod faecal pellets comprised the largest fraction of the faecal material found in the sediment traps, on average accounting for $90 \%$ of total FPC. Of these, pellets with a diameter of 50 to
$90 \mu \mathrm{m}$ produced by older stages of Calanus spp. were the most abundant. The vertical flux of FPC and its contribution to POC export was highest at Stn 74 and was progressively lower at Stns 65 and 100 (Table 1, Fig. 6). Stns 65 and 74 revealed a decrease in FPC flux with depth, whereas this was not apparent at Stn 100. The attenuation of the FPC flux took place in the upper $60 \mathrm{~m}$ at Stn 65, while the flux decreased more gradually throughout the 0 to $200 \mathrm{~m}$ depth range at Stn 74 .

The proportion of faecal pellets to vertical flux of POC, PON and TPP decreased with depth at Stns 65 and 74. At Stn 100, there was a reduction between 20 and $60 \mathrm{~m}$, followed by an increase in the deeper traps (Fig. 4). Faecal pellets contributed equal proportions to POC and PON flux, with averages of 8, 15 and $7 \%$ at Stns 65, 74 and 100, respectively. The FPP contribution to TPP flux was higher, with 13, 28 and $11 \%$ at respective stations. While faecal pellets never accounted for more than $24 \%$ of exported POC and PON, their maximum contribution to TPP flux was $51 \%$. Their mean contribution to vertical flux across all depths and stations was $10 \%$ of POC and PON and $17 \%$ of TPP.

\section{Stoichiometry of suspended and exported organic particles}

The C:N and C:P ratios revealed no consistent variation with depth in either suspended or exported material (not shown). The mean of all depths for suspended C:N varied from 5.0 (Stns B, 65 and 100) to 7.8 (Stn 74; Table 2). The mean C:N of exported particles (5.9-6.7) was closer to Redfield, and the variation among stations was smaller than in suspended particles (Table 2).

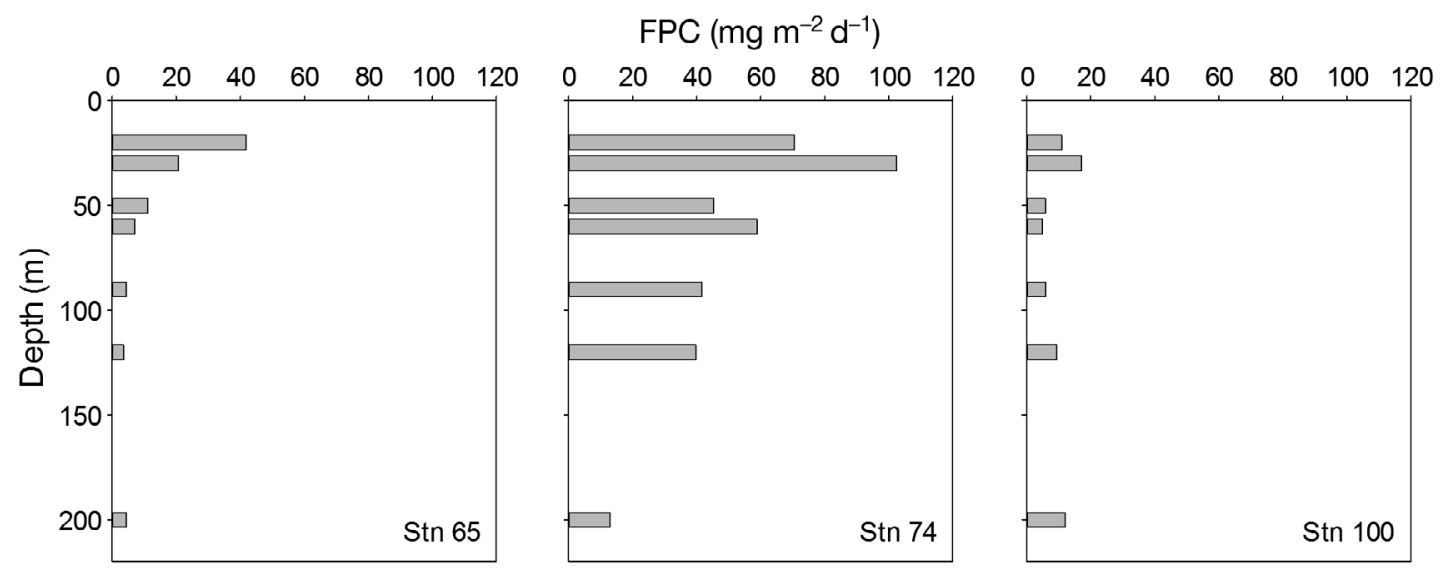

Fig. 6. Vertical flux of faecal pellet carbon (FPC) by copepod faecal pellets at 3 stations 
Table 2. Stoichiometric ratios (mean \pm SD of all depths) of suspended and exported particles and copepod faecal pellets (FP). a:a: atomic ratios; ND: no data

\begin{tabular}{|c|c|c|c|c|c|c|}
\hline \multirow{2}{*}{ Station } & \multicolumn{3}{|c|}{$\longrightarrow$ C:N (a:a) } & \multicolumn{3}{|c|}{$\longrightarrow$ C:P (a:a) } \\
\hline & Suspended & Exported & FP & Suspended & Exported & FP \\
\hline $\mathrm{B}$ & $5.2 \pm 0.2$ & ND & 7.1 & $101 \pm 12$ & ND & 89.8 \\
\hline 65 & $5.0 \pm 0.3$ & $5.9 \pm 0.5$ & 6.6 & $90 \pm 26$ & $112 \pm 12$ & 54.0 \\
\hline 74 & $7.8 \pm 2.3$ & $6.7 \pm 0.4$ & 5.0 & $85 \pm 29$ & $126 \pm 16$ & 55.0 \\
\hline 100 & $5.4 \pm 0.6$ & $6.3 \pm 0.6$ & ND & $97 \pm 23$ & $113 \pm 33$ & ND \\
\hline
\end{tabular}

region during summer (Andreassen et al. 1996, Olli et al. 2002, Reigstad et al. 2008), and higher than in the adjacent Northeast Water Polynya (Bauerfeind et al. 1997). The TPP fluxes are the first to be reported from this region and probably the first from the entire Arctic Ocean. Comparisons to other regions will therefore focus on stoichiometry and retention. The strong positive relationship between

The mean suspended C:P ratio was below Redfield (106) at all stations, and lowest at Stn 74. Conversely, the C:P of exported particles exceeded the Redfield ratio at all stations and was highest at Stn 74 (Table 2). The mean C:P of exported particles was significantly higher than the suspended C:P (t-test, $\mathrm{p}<0.001$, $\mathrm{df}=41$ ). The variability was higher in suspended than in exported C:P ratios, consistent with the patterns in $\mathrm{C}: \mathrm{N}$.

\section{DISCUSSION}

\section{Environmental and ecological settings}

This study is based on 3 discrete observations from different parts of the Fram Strait and the Barents Sea. All sampling locations were dominated by Atlantic water, but differed in terms of water column stratification and biological conditions. Stn 74, located in the central Fram Strait, represents a cold-water spring bloom scenario with strong stratification and high abundance of algal pigments, and dominance of the Arctic zooplankton species Calanus hyperboreus. Stn 65 was characterised by early-bloom conditions with lower abundance of algal pigments, mainly concentrated at the surface. Stn 100 represents a mixing scenario during an ongoing bloom. The mesozooplankton communities at Stns 65 and 100 were dominated by $C$. finmarchicus typical of Atlantic water masses. The Barents Sea station was characteristic of a mixing scenario following a storm. These conditions were important for the observed patterns in vertical flux and for the zooplankton mediation of organic matter export, which will be discussed in the following sections.

\section{Patterns in vertical export and regulating factors}

The vertical flux of POC and PON were within the ranges observed in the Barents Sea and Svalbard vertical flux of POC and chl $a$ indicates that organic matter derived from phytoplankton production was the principal source of exported POC. The high exported POC:chl a ratio (108) suggests a more degraded composition of the exported material than in e.g. Arctic waters of the Barents Sea, where the corresponding ratio was lower $(54$; Reigstad et al. 2008).

The higher contribution of zooplankton faecal pellets to vertical flux at Stn 74 than elsewhere was likely a consequence of higher zooplankton biomass due to the greater abundance of Calanus hyperboreus and older stages (CV and females) of both $C$. finmarchicus and C. hyperboreus. C. hyperboreus is the largest of the 3 Arctic calanoid species, approximately twice as large as C. finmarchicus by prosome length (Karnovsky et al. 2003, Swalethorp et al. 2011) and produces lager faecal pellets (Wexels Riser et al. 2008). Hence, this species has a strong impact both on zooplankton biomass and faecal pellet export. Furthermore, since faecal pellets typically are recycled in the upper part of the water column (Wexels Riser et al. 2007), we hypothesise that the strong and well-defined pycnocline at Stn 74 allowed a high proportion of faecal pellets to be exported because the distance relevant to grazing and pellet degradation was reduced. This is in agreement with observations from the Barents Sea shelf, showing more efficient recycling of faecal pellets in the less stratified Atlantic section compared to the strongly stratified Arctic section (Wexels Riser et al. 2002). In contrast, smaller, slower-sinking particles (algal cells and aggregates) would be retained more efficiently in the water column under stratified conditions. At the other stations, the lower phytoplankton biomass was reflected in lower vertical flux. The smaller proportion of faecal pellets at Stns 65 and 100 was likely due to a combination of the lower biomass of Calanus spp. at these stations and stronger retention of faecal pellets in the water column.

Without sustained production of new autotrophic biomass below the euphotic zone, consumption and 
degradation of organic matter by the pelagic food web reduces the vertical flux with increasing depth. The vertical distance over which elemental fluxes are attenuated varies significantly among geographical regions (Wassmann et al. 2003, Buesseler et al. 2007, Buesseler \& Boyd 2009). In stratified regions such as large parts of the Arctic Ocean and coastal waters, the POC flux typically diminishes strongly in the upper $100 \mathrm{~m}$ and in close proximity to the pycnocline (Wassmann et al. 2003, Reigstad et al. 2008). In the present study, POC fluxes decreased with depth at the 2 stations characterised by stratification in the upper $10 \mathrm{~m}$ (Stns 65 and 100; Table 1). Mixing of the water column at Stn 100 likely caused a redistribution of biomass, resulting in a diffuse pattern of vertical flux and weak reduction with depth. Deep mixing during the productive season caused by atmospheric forcing therefore sets up an active and fast transport of fresh organic matter to deep-water layers and sediments (Reigstad et al. 2008, Renaud et al. 2008). As a consequence, the vertical flux of POC at $200 \mathrm{~m}$ depth was higher at the deeply-mixed Stn 100 than at the stratified Stn 65 although fluxes closer to the surface were lower (Fig. 4). Mixing events related to the cyclic pattern of atmospheric low-pressure systems are a common feature in the Barents Sea during summer and contribute to higher primary production and carbon fluxes to the seabed in the weakly stratified open Barents Sea south of the extent of the seasonal ice cover (Reigstad et al. 2011).

\section{Export stoichiometry and retention efficiency of $\mathbf{C}, \mathbf{N}$ and $\mathbf{P}$}

In the present study, the $\mathrm{C}: \mathrm{N}$ ratios of suspended and exported material were below Redfield at Stns 65 and 100, whereas they were slightly elevated at the peak-bloom Stn 74. The C:N ratios suggest that ice-rafted or terrestrial organic matter which typically has C:N ratios above 10 (Grebmeier et al. 1988, Andreassen et al. 1996, Tamelander et al. 2009) was not an important source to vertical export. Stoichiometric ratios are also influenced by the species composition of primary producers, revealed in higher $\mathrm{C}: \mathrm{N}$ ratios of exported organic matter in the diatom-dominated Arctic section of the Barents Sea compared to the Phaeocystis-dominated Atlantic section (Olli et al. 2002). Information on the species composition of phytoplankton is not available, and therefore we cannot evaluate this source of variation.
The mean $\mathrm{C}: \mathrm{N}$ ratio of exported particles was the same as in suspended particles, indicating that carbon and nitrogen were exported in the same proportions. This is supported by the lack of change in C:N ratios with depth, both in suspended and exported particles. In reviewing remineralisation rates, Boyd \& Trull (2007) found nitrogen to be remineralised faster than carbon in most areas investigated, but not in all. Their compilation of data did not include observations from the Arctic or other strongly stratified regions, however. The present results agree with earlier studies in the European Arctic showing that carbon and nitrogen are exported from the upper $200 \mathrm{~m}$ in the same proportions during summer (Olli et al. 2002, Reigstad et al. 2008).

There are few reports on C:P stoichiometry of exported organic matter from primarily nitrogenlimited regions such as the Arctic Ocean. In the primarily nitrogen-limited Baltic Sea, the retention efficiencies of carbon, nitrogen, and phosphorus vary both spatially and seasonally, with phosphorus being retained up to 5 times more efficiently than carbon in the upper water column during spring (Heiskanen et al. 1998, Reigstad et al. 1999). In large parts of the ocean, phosphorus appears to be mineralised faster than carbon and approximately at the same rate as nitrogen (Loh \& Bauer 2000, Boyd \& Trull 2007). The consistently higher C:P of exported particles compared to suspended ones in the present study indicates that phosphorus remineralises faster than carbon and nitrogen and that carbon and nitrogen were exported in equal proportions. Phosphorus lost from senescent phytoplankton is remineralised within hours and recycling is faster than for carbon and nitrogen (Garber 1984). Phosphorus-starved phytoplankton and bacteria also solubilise phosphorus enzymatically from complex molecules by alkaline phosphatase, thereby contributing to its retention in the water column (Thingstad et al. 1998). Based on the average suspended and exported C:P ratios, phosphorus was retained 1.2 to 1.4 times more efficiently than carbon, with the highest retention efficiency at Stn 74, which was characterised by peak-bloom conditions. These inferred retention efficiencies are 2 orders of magnitude below those observed in the P-limited subtropical North Pacific (Hannides et al. 2009). The lack of significant changes in the C:N and C:P ratios of exported particles with depth suggests that phosphorus is derived from particles close to the surface (i.e. above $20 \mathrm{~m}$ ) and that sinking particles retain their properties at least within the depth range of $200 \mathrm{~m}$ considered in this study. 


\section{Potential for $\mathbf{P}$ export through copepod faecal pellets}

Although zooplankton faecal pellets generally are efficiently recycled in the water column, the small but variable fraction escaping destruction and degradation contributes to vertical export of organic matter from the water column (Viitasalo et al. 1999, Wexels Riser et al. 2007). Turner (2002) estimated that faecal pellets on average contribute $20 \%$ of exported POC where this proportion has been determined. Their potential as loss factors for nitrogen and phosphorus from the water column has received less attention, however. This study suggests that faecal pellets are a phosphorus-rich source of organic matter, contributing to a relatively higher proportional export of phosphorus than of carbon and nitrogen. The elemental composition of faecal pellets mainly varied in terms of carbon content among stations, possibly relating to the variation in the composition of suspended particulate organic matter that was used as a diet (Daly 1997). Taking the variation in faecal pellet carbon content into account would have increased the C:P ratio of faecal pellets to 104 at the most. This is below the C:P of the exported organic matter, which corroborates our finding that faecal pellets are a stronger loss factor for phosphorus than for carbon and nitrogen from the water column. Our estimates of a $17 \%$ contribution of faecal pellets to TPP export and 10\% to PON should be considered conservative since the nitrogen and phosphorus contents were only determined in copepod pellets. However, these estimates should be representative of Arctic marine systems since copepods typically dominate the mesozooplankton communities in these regions. Pellets from appendicularians and krill are temporarily abundant in sediment trap samples (Wexels Riser et al. 2008), but without knowledge of their phosphorus content, their contribution to phosphorus export cannot be quantified.

The results suggest that leaching of phosphorus from senescent phytoplankton to the surrounding water is delayed when cells are packed in faecal pellets. The larger volume:surface ratio of aggregates and pellets compared to single cells or algal colonies also means that less substrate is exposed to alkaline phosphatase present in the environment, and the solubilisation of phosphorus from these particles may thus be reduced. Although their average contribution to phosphorus export was only $7 \%$ higher than to carbon and nitrogen export, faecal pellets may nevertheless provide a mechanism for fast removal of phosphorus from the water column under conditions favouring retention of slower-sinking detritus. Given the low C:P ratio of faecal pellets, the high faecal pellet flux at Stn 74 seems to disagree with the C:P ratio of total exported particulate organic matter being highest at this station. Another unidentified fraction of the sinking material must therefore have been enriched in carbon in order to produce this pattern.

This study shows that sinking of large zooplankton faecal pellets provides an important mechanism for removal of phosphorus from the water column. The relative importance of this pathway is likely augmented under strongly stratified conditions when smaller, slower-sinking detritus is recycled. Increasing the number of observations in a future study to include scenarios where faecal pellets are more abundant would be important in order to further evaluate their role for phosphorus export.

Acknowledgements. We thank M. Reigstad (University of Tromsø) for $\mathrm{C}$ and $\mathrm{N}$ analyses and K. A. Mork (Institute of Marine Research, Norway) for providing the CTD data. We also thank the captain and crew of RV 'GO Sars' for skilful assistance during the field campaign. Three anonymous reviewers are acknowledged for comments that improved the paper. We thank J. Turner for English editing. This study was funded by the Research Council of Norway through the project MERCLIM 'Marine Ecosystem Response to a Changing Climate', no. 184860/S30.

\section{LITERATURE CITED}

Andreassen I, Nothig EM, Wassmann P (1996) Vertical particle flux on the shelf off northern Spitsbergen, Norway. Mar Ecol Prog Ser 137:215-228

Bauerfeind E, Garrity C, Krumbholz M, Ramseier RO, Voss M (1997) Seasonal variability of sediment trap collections in the Northeast Water Polynya. 2. Biochemical and microscopic composition of sedimenting matter. J Mar Syst 10:371-389

Blachowiak-Samolyk K, Kwasniewski S, Richardson $\mathrm{K}$, Dmoch K and others (2006) Arctic zooplankton do not perform diel vertical migration (DVM) during periods of midnight sun. Mar Ecol Prog Ser 308:101-116

Blachowiak-Samolyk K, Soreide JE, Kwasniewski S, Sundfjord A, Hop H, Falk-Petersen S, Hegseth EN (2008) Hydrodynamic control of mesozooplankton abundance and biomass in northern Svalbard waters $\left(79-81^{\circ} \mathrm{N}\right)$. Deep-Sea Res II 55:2210-2224

> Boyd PW, Trull TW (2007) Understanding the export of biogenic particles in oceanic waters: Is there consensus? Prog Oceanogr 72:276-312

> Buesseler KO, Boyd PW (2009) Shedding light on processes that control particle export and flux attenuation in the twilight zone of the open ocean. Limnol Oceanogr 54: 1210-1232

Buesseler KO, Lamborg CH, Boyd PW, Lam PJ and others (2007) Revisiting carbon flux through the ocean's twilight zone. Science 316:567-570

Checkley DM, Entzeroth LC (1985) Elemental and isotopic 
fractionation of carbon and nitrogen by marine, planktonic copepods and implications to the marine nitrogencycle. J Plankton Res 7:553-568

Conover RJ, Huntley M (1991) Copepods in ice-covered seas: distribution, adaptations to seasonally limited food, metabolism, growth patterns and life cycle strategies in polar seas. J Mar Syst 2:1-41

Coppola L, Roy-Barman M, Wassmann P, Mulsow S, Jeandel C (2002) Calibration of sediment traps and particulate organic carbon export using Th-234 in the Barents Sea. Mar Chem 80:11-26

> Cottier FR, Tarling GA, Wold A, Falk-Petersen S (2006) Unsynchronized and synchronized vertical migration of zooplankton in a high arctic fjord. Limnol Oceanogr 51: 2586-2599

> Daly K (1997) Flux of particulate matter through copepods in the Notheast Water Polynya. J Mar Syst 10:319-342

> Daly KL, Wallace DWR, Smith WO, Skoog A and others (1999) Non-Redfield carbon and nitrogen cycling in the Arctic: effects of ecosystem structure and dynamics. J Geophys Res 104:3185-3199

> Damm E, Helmke E, Thoms S, Schauer U, Nothig E, Bakker K, Kiene RP (2010) Methane production in aerobic oligotrophic surface water in the central Arctic Ocean. Biogeosciences 7:1099-1108

> Forest A, Wassmann P, Slagstad D, Bauerfeind E, Nothig EM, Klages M (2010) Relationships between primary production and vertical particle export at the AtlanticArctic boundary (Fram Strait, HAUSGARTEN). Polar Biol 33:1733-1746

> Garber JH (1984) Laboratory study of nitrogen and phosphorus remineralization during the decomposition of costal plankton and seston. Estuar Coast Shelf Sci 18: 685-702

Grebmeier JM, McRoy CP, Feder HM (1988) Pelagic-benthic coupling on the shelf off the northern Bering and Chukchi Seas. 1. Food supply source and benthic biomass. Mar Ecol Prog Ser 48:57-67

Hannides CCS, Landry MR, Benitez-Nelson CR, Styles RM, Montoya JP, Karl DM (2009) Export stoichiometry and migrant-mediated flux of phosphorus in the North Pacific Subtropical Gyre. Deep-Sea Res I 56:73-88

> Heiskanen AS, Haapala J, Gundersen K (1998) Sedimentation and pelagic retention of particulate $\mathrm{C}, \mathrm{N}$ and $\mathrm{P}$ in the coastal northern Baltic Sea. Estuar Coast Shelf Sci 46: 703-712

> Holm-Hansen O, Riemann B (1978) Chlorophyll a determination - improvements in methodology. Oikos 30: 438-447

Karl DM, Bjorkman KM, Dore JE, Fujieki L and others (2001) Ecological nitrogen-to-phosphorus stoichiometry at station ALOHA. Deep-Sea Res II 48:1529-1566

Karnovsky NJ, Kwasniewski S, Weslawski JM, Walkusz W, Beszczynska-Möller A (2003) Foraging behavior of little auks in a heterogeneous environment. Mar Ecol Prog Ser 253:289-303

Körtzinger A, Koeve W, Kahler P, Mintrop L (2001) C:N ratios in the mixed layer during the productive season in the northeast Atlantic Ocean. Deep-Sea Res I 48:661-688

> Lalande C, Moran SB, Wassmann P, Grebmeier JM, Cooper LW (2008) Th-234-derived particulate organic carbon fluxes in the northern Barents Sea with comparison to drifting sediment trap fluxes. J Mar Syst 73:103-113

> Lalande C, Forest A, Barber DG, Gratton Y, Fortier L (2009) Variability in the annual cycle of vertical particulate organic carbon export on Arctic shelves: contrasting the Laptev Sea, Northern Baffin Bay and the Beaufort Sea. Cont Shelf Res 29:2157-2165

Loh AN, Bauer JE (2000) Distribution, partitioning and fluxes of dissolved and particulate organic C, N and P in the eastern North Pacific and Southern Oceans. DeepSea Res I 47:2287-2316

Mei ZP, Legendre L, Tremblay JE, Miller LA and others (2005) Carbon to nitrogen (C:N) stoichiometry of the spring-summer phytoplankton bloom in the North Water Polynya (NOW). Deep-Sea Res I 52:2301-2314

Olli K, Wexels Riser C, Wassmann P, Ratkova T, Arashkevich E, Pasternak A (2002) Seasonal variation in vertical flux of biogenic matter in the marginal ice zone and the central Barents Sea. J Mar Syst 38:189-204

Redfield AC (1934) On the proportions of organic derivatives in sea water and their relation to the composition of plankton. In: Daniel RJ (ed) James Johnstone Memorial Volume. University Press of Liverpool, Liverpool, p 176-192

Redfield AC, Ketchum BH, Richards FH (1963) The influence of organisms on the composition of seawater. In: Hill MN (ed) The sea, Vol 2. John Wiley \& Sons, New York, NY, p 26-77

> Reigstad M, Heiskanen AS, Wassmann P (1999) Seasonal and spatial variation of suspended and sedimented nutrients $(C, N, P)$ in the pelagic system of the Gulf of Riga. J Mar Syst 23:211-232

Reigstad M, Wexels Riser C, Svensen C (2005) Fate of copepod faecal pellets and the role of Oithona spp. Mar Ecol Prog Ser 304:265-270

Reigstad M, Wexels Riser C, Wassmann P, Ratkova T (2008) Vertical export of particulate organic carbon: attenuation, composition and loss rates in the northern Barents Sea. Deep-Sea Res II 55:2308-2319

Reigstad M, Carroll J, Slagstad D, Ellingsen I, Wassmann P (2011) Intra-regional comparison of productivity, carbon flux and ecosystem composition within the northern Barents Sea. Prog Oceanogr 90:33-46

Renaud PE, Morata N, Carroll ML, Denisenko SG, Reigstad M (2008) Pelagic-benthic coupling in the western Barents Sea: processes and time scales. Deep-Sea Res II 55: 2372-2380

Sabatini M, Kiørboe T (1994) Egg-production, growth and development of the cyclopoid copepod Oithona similis. J Plankton Res 16:1329-1351

Sallon A, Michel C, Gosselin M (2011) Summertime primary production and carbon export in the southeastern Beaufort Sea during the low ice year of 2008. Polar Biol 34: 1989-2005

> Sampei M, Sasaki H, Forest A, Fortier L (2012) A substantial export flux of particulate organic carbon linked to sinking dead copepods during winter 2007-2008 in the Amundsen Gulf (southeastern Beaufort Sea, Arctic Ocean). Limnol Oceanogr 57:90-96

> Smith W, Gosselin M, Legendre L, Wallace D, Daly K, Kattner G (1997) New production in the Northeast Water Polynya: 1993. J Mar Syst 10:199-209

Steinberg DK, Cope JS, Wilson SE, Kobari T (2008) A comparison of mesopelagic mesozooplankton community structure in the subtropical and subarctic North Pacific Ocean. Deep-Sea Res II 55:1615-1635

> Sterner RW, Andersen T, Elser JJ, Hessen DO, Hood JM, McCauley E, Urabe J (2008) Scale-dependent carbon: nitrogen: phosphorus seston stoichiometry in marine and 
freshwaters. Limnol Oceanogr 53:1169-1180

Strickland JDH, Parsons TR (1965) A manual of sea water analysis, 2nd edn. Fisheries Research Board of Canada, Ottawa

Svensen C, Seuthe L, Vasilyeva Y, Pasternak A, Hansen E (2011) Zooplankton distribution across Fram Strait in autumn: Are small copepods and protozooplankton important? Prog Oceanogr 91:534-544

Swalethorp R, Kjellerup S, Dünweber M, Nielsen TG, Møller EF, Rysgaard S, Hansen BW (2011) Grazing, egg production, and biochemical evidence of differences in the life strategies of Calanus finmarchicus, C. glacialis and C. hyperboreus in Disko Bay, western Greenland. Mar Ecol Prog Ser 429:125-144

Tamelander T, Reigstad M, Hop H, Ratkova T (2009) Ice algal assemblages and vertical export of organic matter from sea ice in the Barents Sea and Nansen Basin (Arctic Ocean). Polar Biol 32:1261-1273

Tamminen T, Seppälä J (1999) Nutrient pools, transformations, ratios, and limitation in the Gulf of Riga, the Baltic Sea, during four successional stages. J Mar Syst 23: 83-106

Thingstad TF, Rassoulzadegan F (1995) Nutrient limitations, microbial food webs, and 'biological C-pumps': suggested interactions in a P-limited Mediterranean. Mar Ecol Prog Ser 117:299-306

Thingstad TF, Zweifel UL, Rassoulzadegan F (1998) P limitation of heterotrophic bacteria and phytoplankton in the northwest Mediterranean. Limnol Oceanogr 43:88-94

Tian RC, Deibel D, Thompson RJ, Rivkin RB (2003) Modeling of climate forcing on a cold-ocean ecosystem, Conception Bay, Newfoundland. Mar Ecol Prog Ser 262:1-17

- Tremblay JE, Gratton Y, Fauchot J, Price NM (2002) Climatic and oceanic forcing of new, net, and diatom production in the North Water. Deep-Sea Res II 49: 4927-4946

Turner JT (2002) Zooplankton fecal pellets, marine snow and sinking phytoplankton blooms. Aquat Microb Ecol $27: 57-102$

Editorial responsibility: Katherine Richardson, Copenhagen, Denmark
Vidal M, Duarte CM, Agusti S, Gasol JM, Vaque D (2003) Alkaline phosphatase activities in the central Atlantic Ocean indicate large areas with phosphorus deficiency. Mar Ecol Prog Ser 262:43-53

> Viitasalo M, Rosenberg M, Heiskanen AS, Koski M (1999) Sedimentation of copepod fecal material in the coastal northern Baltic Sea: Where did all the pellets go? Limnol Oceanogr 44:1388-1399

Walve J, Larsson U (1999) Carbon, nitrogen and phosphorus stoichiometry of crustacean zooplankton in the Baltic Sea: implications for nutrient recycling. J Plankton Res 21:2309-2321

Wassmann P, Olli K, Wexels Riser C, Svensen C (2003) Ecosystem function, biodiversity and vertical flux regulation in the twilight zone. In: Wefer G, Lamy F, Mantoura $\mathrm{F}$ (eds) Marine science frontiers for Europe. SpringerVerlag, Berlin, p 279-287

Wassmann P, Bauerfeind E, Fortier M, Fukuchi M and others (2004) Particulate organic carbon flux to the Arctic Ocean sea floor. In: Stein R, Macdonald RW (eds) The organic carbon cycle in the Arctic Ocean. SpringerVerlag, Berlin, p 101-138

> Wassmann P, Slagstad D, Wexels Riser C, Reigstad M (2006) Modelling the ecosystem dynamics of the Barents Sea including the marginal ice zone II. Carbon flux and interannual variability. J Mar Syst 59:1-24

> Wexels Riser C, Wassmann P, Olli K, Pasternak A, Arashkevich $E$ (2002) Seasonal variation in production, retention and export of zooplankton faecal pellets in the marginal ice zone and central Barents Sea. J Mar Syst 38:175-188

- Wexels Riser C, Reigstad M, Wassmann P, Arashkevich E, Falk-Petersen S (2007) Export or retention? Copepod abundance, faecal pellet production and vertical flux in the marginal ice zone through snap shots from the northern Barents Sea. Polar Biol 30:719-730

> Wexels Riser C, Wassmann P, Reigstad M, Seuthe L (2008) Vertical flux regulation by zooplankton in the northern Barents Sea during Arctic spring. Deep-Sea Res II 55: $2320-2329$

Submitted: September 14, 2011; Accepted: March 21, 2012 Proofs received from author(s): July 7, 2012 